\title{
HABITATS, POPULATION DENSITIES, AND SOCIAL STRUCTURE OF CAPYBARAS (HYDROCHAERIS HYDROCHAERIS, RODENTIA) IN THE PANTANAL, BRAZIL
}

Cleber J.R. Alho ${ }^{1}$

Nelson L. Rondon ${ }^{2}$

\section{ABSTRACT}

(1) The Pantanal is the central portion of a sunken flat plain bordering the upper Paraguay river, with an area of $140,000 \mathrm{~km}^{2}$. Seasonal floods begin in January and end in April. From May to October the land dries out and campos (grassland formations) and scattered pools appear.

(2) Typical capybara habitat in the Pantanal is composed of three components: the water, a patch of forest, and a grass field for foraging. Highest densities of capybaras (14 individuals $/ \mathrm{km}^{2}$ ) were found during the rainy season when the available space for capybaras was reduced due to the flooding. Areas without ponds or creeks presented low densities (from 0.38 to 0.84 capybaras $\left(\mathrm{km}^{2}\right)$. Group sizes ranged from 2 to 49 individuals $(\bar{x}=9.48)$.

(3) Reproduction occurred year-round and young of different ages were seen throughout the year. However, the principal recruitment of young to the population was observed in July-August. While the females took turns in caring for young of different ages, probably the offspring of mothers who are sisters in the same social groups, the males competed intensively with each other for access to breeding females. The male's reproductive success appears to be limited to the number of breeding females that males have access to in the social group.

\section{INTRODUCTION}

The capybara, Hydrochaeris hidrochaeris, is the largest rodent in the world, with adult individuals ranging in weight from 30 to $70 \mathrm{~kg}$. It is a se-

1 Universidade de Brasília, Departamento de Biologia Animal, Laboratório de Zoolo. gia e Ecologia Animal, 70910 Brasília - DF, Brazil.

2 Universidade Federal de Mato Grosso, Departamento de Engenharia Florestal. 78000 Cuiabá - MT, Brasil. 
mi-aquatic herbivore whose range spans much of South America, inhabiting river basins from Panama southwards to Uruguay and Northern Argentina (Alho, 1982).

The ecology of the capybara in Venezuela and Colombia was studied by Azcarate (1976); Gil, Perea \& Ruiz (1976); Ojasti (1968, 1973, 1978); Ojasti \& Medina-Padilla (1972). Some aspects of their behaviour were studied by Azcarate (1980); and some applied biology was discussed by Escobar \& Gonzalez-Jimenez (1976), and Gonzalez-Jimenez (1977). The most recent work was conducted in Venezuela by MacDonald (1981). The only published paper on capybaras in Brazil was that by Schaller \& Crawshaw (1981) on social organization in a capybara population in the Pantanal. Additional information on capybaras in zoological parks outside South America is provided by Donaldson, Wirtz \& Hite (1975) and Zara (1973).

Although capybaras are widely distributed and particularly abundant in some habitats in Brazil, no comprehensive, year-round investigations have been carried out under natural conditions on the ecology and behaviour of natural populations. The species ecology, population structure, behaviour and habitat preferences were studied in order to develop strategies for its conservation.

The purpose of the present study is to determine the population sizes for free-ranging capybaras in their natural habitats in the Pantanal of Western Brazil and to interpret the reproductive strategy within the social system of the capybara groups.

\section{STUDY AREA}

The Pantanal is the central portion of a sunken flat plain bordering the upper Paraguay river (Fig. 1). The climate is tropical semi-humid and the vevetation consists of marshes, seasonal flooded grasslands interspersed with clumps or strips of semi-deciduous forest, and patches of cerrado, and a denser kind of cerrado or cerradão. The Pantanal is located near the geographic center of South America. The Cuiabá River is a part of the Pantanal depression and includes an area of about $140,000 \mathrm{~km}^{2}$ in Brazil, between the latitudes $19^{\circ}$ and $22^{\circ} 30^{\circ} \mathrm{S}$, being $450 \mathrm{~km}$ long and $280 \mathrm{~km}$ wide at the latitude of Corumbá. The Pantanal extends only slightly into Bolivia and Paraguay. The surface slope patterns create three major provinces: the upper Pantanal, the middle Pantanal and the lower Pantanal, each with a typical vegetation formation. In the upper Pantanal, flooding is localized and the water level rises 30 to $40 \mathrm{~cm}$ and lasts for 2 to 3 months a year. The dominant vegetation types are campo (a grassland formation), cerrado (a savanna woodland) and forest. The middle Pantanal is a transition zone with deeper flooding, wich lasts for 3 to 4 months. The lower Pantanal is composed of seasonally flooded campos cut by forests, where the area is extremely flat. 


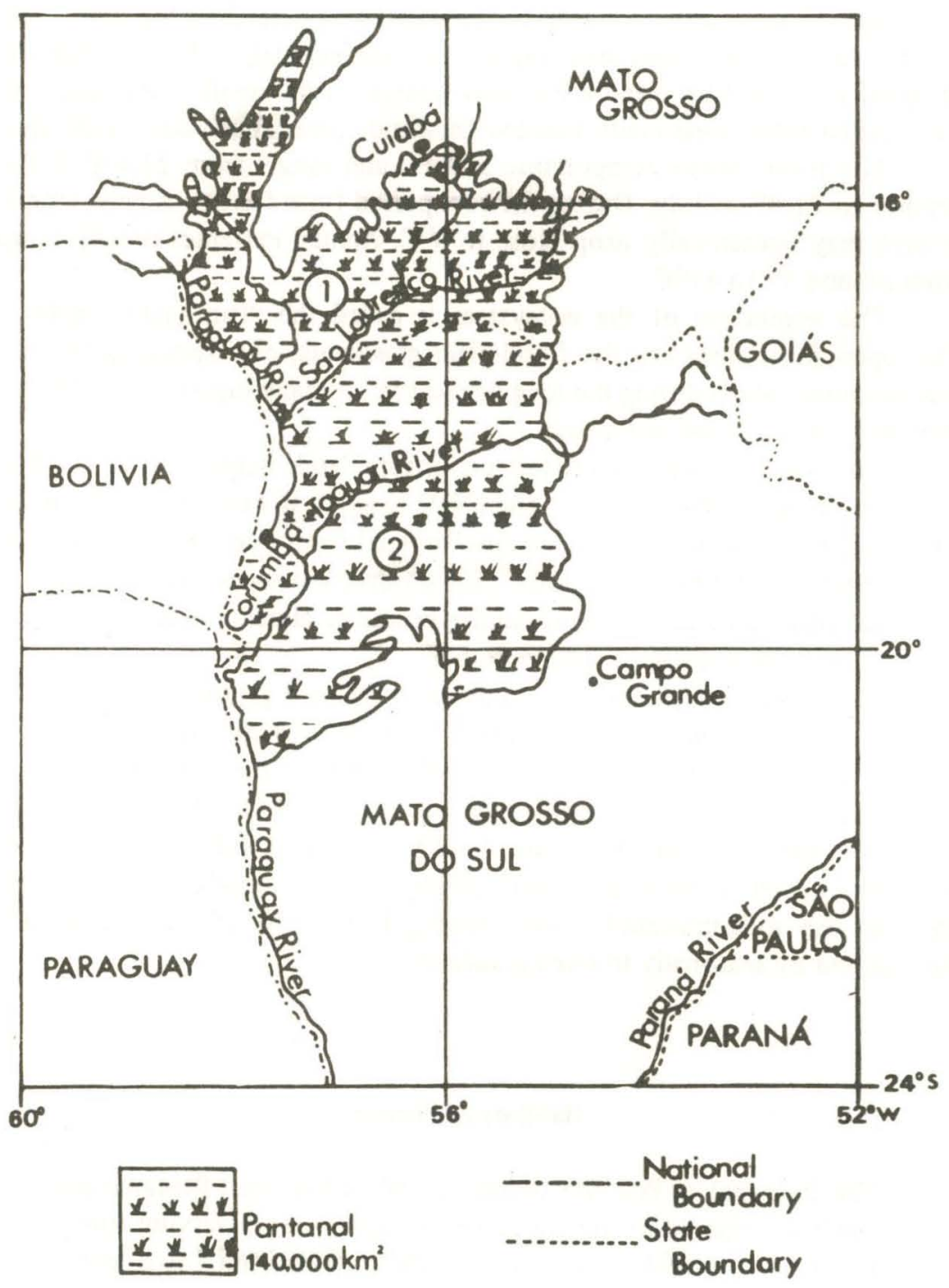

Fig. 1 - The Pantanal of western Brazil where capybaras are still abundant. This biome is one of the Neotropics' largest swamplant wilderness. 
The study areas of Poconé and Nhecolândia are both located in the lower province of the Pantanal.

Floods begin in January and end in April. From May to October the land dries out and the campos and scattered pools appear. Maximum rainfall occurs in December and January with an annual average precipitation of $1300 \mathrm{~mm}$. Floods begin in the upper Pantanal and extend to the lower. Since the land is flat, large areas rapidly become inundated. The peculiar hydrography of the Nhecolândia Pantanal creates several small round lakes, locally called baias. Seasonally flooded grasslands cover about $20 \%$ of the area.

The mean annual temperature is $25^{\circ} \mathrm{C}$ and ranges from $27,4^{\circ} \mathrm{C}$ in December to $21.4^{\circ}$ in July. During the cool period from June to August temperatures may occasionally drop close to $0^{\circ} \mathrm{C}$. Annual extremes usually range from around $5^{\circ}$ to $41^{\circ} \mathrm{C}$.

The vegetation of the ecosystem is called the "Pantanal Complex". The open formations are the flood-plain grasslands, corresponding to treeless savannas, which during the long dry season, in many higher areas, develop into bush savannas and woodland.

Our research was conducted on private land, mainly cattle ranches, close to the research station of IBDF-DN located at kilometer 115 on the Transpantaneira Road that crosses the Pantanal from Poconé to Porto Jofre, in the State of Mato Grosso. Some field observations were also made at the Fazenda Nhumirim in the Nhecolândia Pantanal, about $150 \mathrm{~km} \mathrm{SE} \mathrm{of} \mathrm{Co-}$ rumbá, in the State of Mato Grosso do Sul.

The vegetation of the two study areas differed greatly. In Poconé the patches of forest have a high, closed canopy $(15-20 \mathrm{~m})$ and the trees are mostly drought-deciduous. In Nhecolândia, cerrado and cerradôes (a denser cerrado) replace the taller forest. The area most closely resembles the cerrado of central Brazil. The water used by capybaras in Poconé is in form of creeks named corixos and small ponds, whereas in Nhecolândia the capybaras use medium-sezed ponds varying from 5 to 25 ha in area, and surrounded by seasonally flooded grassland.

\section{Habitats of Pocone}

The Pantanal of Poconé comprises $13 \%$ of the total Pantanal area and has a medium inundation regime with the water depth varying from a few centimeters up to 6 meters and with flooding lasting from 4 to 8 months per year. The corixos cut the seasonally flooded grasslands. Gallery forest, or cordilheiras, grow on higher elevations that are rarely flooded. This vegetation is about $15 \mathrm{~m}$ high and has a closed canopy. Herbaceous vegetation is lacking. Some cordilheiras, known as campos de cambarazais, are semi-open and dominated by the species Vochysia divergens. The type of woodland contains herbaceous vegetation. 
The grasslandi are natural pastures cut by the cordilheiras and corixos. In some areas there are relatively dense populations of spiny shrubs (Mimosa sp). about $50 \mathrm{~cm}$ high. In some of the campos the grasses cover about $90 \%$ of the ground. Paspalum notatum gives these areas their bright green color. This habitat is occupied in large part by grasses, herbs and shrubs including the following species which our. observations showed to serve as food for the capybaras: Pontederia lanceolata, Echinodorus tenellus, Cyperus sesquiflorus, Eleocharis fistulosa, Aeschnomene sensitiva, Teramus sp. and Vigna sp. Usually these campos are overgrazed by.wild herbivores and cattle which makes plant identification difficult. Close to the water the campo gives way to a dense shrub community, principally of Ipomoea fistulosa and Discolobium pulchellum. In this flooded area the commom species are Aeschynomene sp. which the capybaras use as a food, and Eichhornia crassipes, as well as other floating plants. In dry areas close to the water, Paspalum notatum, Salvinia auriculata, and other species provide ground cover.

\section{Habitats of Nhecolândia}

The Pantanal of Nhecolândia comprises $17 \%$ of the total Pantanal area and is also an area of medium inundation. Water depth here varies from a few centimeters to $4 \mathrm{~m}$ and the flood season may range from 4 to 6 months. The forest patches, or capóes de mata are cerrado or cerradão with guatambu (Aspidosperma olivacea), aroeira (Astronium urundeuva), angelim (Andira cuyabensis), paratudo (Tabebuia caraiba), puíva (Tabebuia impetiginosa), acuri (Scheelea phalerata) piúva cascuda (Tabebuia ochracea), and other trees. Some capões are dominated by the palm carandá (Copernicia australis) and bocaiuva (Acrocomia sclerocarpa). The natural pastures are composed essentially of Axonopus purpusii, Mesosetum loliiforme and Panicum. laxum, all eaten by capybaras. Pott (1982) pointed out that legumes, such as Desmodium barbatum and fura-bucho (Paspalum sp.) are also abundant and other plants, such as Helicteres sacarolha, Ocotea sp. and Tocoyena formosa are only occasional components of the diet of capybaras. The natural pastures, where grasses are dominant, have been invaded by low trees and shrubs such as Bromelia balansea, Byrsonima intermedia and Vernonia scabra. Other species that possibly serve as food for the capybaras are Andropogon bicornis, A. hypogynus, A. selloanus, Axonopus leptotachyus, Elionuros candidus, Gymnopogon sp., Ichnanthus procurrens, Panicum sp., Paspalum plicatulum, Paspalum sp., Raimarochloa brasiliensis, Setaria geniculata and Trachypogon sp. (Pott, 1982).

The ponds, or baias, are surrounded by Graminae and Cyperaceae, but when they become dry they are invaded by shrubs. 


\section{METHODS}

The field work was conducted from January 1983 to January 1984. We censused capybara populations in both Poconé and Nhecolândia. In Pocone we counted group sizes twice a day, 10 days per month, over the course of 1 year within an area of $250 \mathrm{~km}^{2}$. Thus, during 10 consecutive days of each month, from 07.00 to 18.00 hours, census studies were exhaustively carried out spanning the two different seasons. Each day the census routes were covered, one in the morning, the other in the afternoon until dusk, alternating the order morning-afternoon to obtain a balanced coverage of capybara groups observed in different activities. Two to four searched the census route by car, recording the identity of the social group, position, activity, number of animals in the group, sexes, size classes, and location of each animal seen. In the Pantanal, capybaras are accustomed to the presence of cars and allow the presence of observers in a jeep rather than someone walking. Since groups frequently encountered in the same general area, we were able to obtain data on the average size of each of the groups in the census area. We conducted censuses in the same manner in Nhecolândia during 3 months of the dry season (July, August and September) in an area of $120 \mathrm{~km}^{2}$.

Adult males were distinguished from adult females by the presence of a protuberance, the supranasal gland, on the snout (Rewell 1950; MacDonald, Krantz \& Aplin 1984). Sub-adults and young were not separated by sex. We distinguished only three age classes: young, sub-adults and adults. Young have a slightly brighter color and texture to the pelage. Weights varied between approximately 1.5 and $10 \mathrm{~kg}$. Sub-adults were animals between 6 and 10 months of age. They were distinguished on the basis of size and lack of either adult or youg characteristics. Animals of 14 months or older are clearly adults and possess adult secondary sexual characteristics. Misclassification by age occurred most frequently with the few individuals that were transitional between any two of the above age classes. We were able to categorize individuals by age and/or sex in $80 \%$ of the observations.

We present estimates of both crude density and ecological density. The estimates of crude density represent the number of animals occurring over the entire area censused $\left(250 \mathrm{~km}^{2}\right.$ in Poconé and $120 \mathrm{~km}^{2}$ in Nhecolândia). The estimates of ecological density represent the number of animals occurring only in habitats most used by capybaras; as a consequence these figures are always higher than those for crude density although the figures changed from month to month. We calculated density by summing the average number of individuals per group for all groups present, then dividing by the area. The area used in the denominator was the total area of the census for crude density and the total area of available capybara habitat for ecological density, that is, the habitat offering water, a patch of forest and pasture which constituted the most used area by capybaras. Areas not considered as suitable capybara habitat included large lakes, elevated plateaus, extensive stands of 
forest, and heavily manipulated ranch and farm lands. Densities were converted to biomass by multiplying the number of individuals by the average weight of a capybara (30 kg) (Eisenberg, O'Connell \& August, 1979).

One area, the Capão do Júlio, was more intensively studied in order to collect data on social organization. All observations were collected on one group of 14 capybaras of known sex and age. Animals were observed between 06.00 and 18.00 (or until dark) for 10 days each month throughout the course of 1 year. Observations were made with binoculars from behind a blind. Every 10 minutes, the behaviour of all animals visible $(\leqslant 14)$ was noted. This group was observed in an area with all three of the habitat components utilized by capybaras (forest, campo and water).

\section{RESULTS AND DISCUSSION}

\section{Densities of Capybaras in the Pantanal}

We observed the highest ecological densities of capybaras during the rainy season, between January and April (Table 1). The higher densities observed during the rainy season are due to the reduced available space for the capybaras due to the flooding of large areas of campos.

During the period of the year groups were more concentrated in higher areas (capões and cordilheiras) which were easier to locate during the flood season. The animals are more aggregated within the available space. The flooding affects crude densities because animals apparently move into the study area escaping from nearby areas now inundated. The lowest densities of capybaras were observed in acurizal habitat of the Pantanal of Poconé. Acurizal is dominated by the palm acuri (Scheelea phalerata) and has no

Table 1 - Density, group size, and biomass of capybaras at Poconé and Nhecolândia in the Brazilian Pantanal. Data from Poconé and Nhecolândia are combined (Nhecolândia was censused only during the dry season) as there were no differences in densities and group sizes between the two sites.

\begin{tabular}{|c|c|c|c|c|c|c|c|c|c|}
\hline \multirow[t]{2}{*}{ Months } & \multirow{2}{*}{$\begin{array}{l}\text { Eco- } \\
\text { logi- } \\
\text { cal } \\
\text { den- } \\
\text { sity } \\
\left(\mathrm{km}^{2}\right)\end{array}$} & \multirow{2}{*}{$\begin{array}{l}\text { Number } \\
\text { of } \\
\text { groups } \\
\text { seen } \\
\text { and } \\
\text { counted }\end{array}$} & \multirow[t]{2}{*}{$\begin{array}{l}\text { Mean } \\
\text { group } \\
\text { size }\end{array}$} & \multirow{2}{*}{$\begin{array}{c}\text { Standard } \\
\text { error }\end{array}$} & \multicolumn{2}{|c|}{$\begin{array}{l}\text { Mean } \\
\text { Range }\end{array}$} & \multirow{2}{*}{$\begin{array}{l}\text { Estima- } \\
\text { ted } \\
\text { crude } \\
\text { density } \\
\left(\mathrm{km}^{2}\right)\end{array}$} & \multicolumn{2}{|c|}{$\begin{array}{c}\text { Estimated } \\
\text { Biomass } \\
\left(\mathrm{kg} / \mathrm{km}^{2}\right)\end{array}$} \\
\hline & & & & & $\max$ & $\min$. & & $\begin{array}{l}\text { Ecolo- } \\
\text { gical }\end{array}$ & Crude \\
\hline J-F & 14.6 & 35 & 81 & 24 & 34.0 & 1. & 0.44 & 43 & 13.2 \\
\hline M-A & 14.82 & 89 & 6.34 & 1. & 32.0 & 0.2 & 0.84 & 444.6 & 25.2 \\
\hline M-J & 5.43 & 92 & 9.26 & 0.37 & 22.0 & 0.3 & 0.39 & 162.9 & 11.7 \\
\hline$J-A$ & 7.94 & 79 & 13.18 & 0.35 & 14.6 & 0.4 & 0.45 & 238.2 & 13.5 \\
\hline $\mathrm{S}-\mathrm{O}$ & 7.62 & 64 & 11.83 & 0.34 & 13.3 & 0.4 & 0.38 & 228.6 & 11.4 \\
\hline$N-D$ & 6.48 & 61 & 9.97 & 0.59 & 23.3 & 0.4 & 0.64 & 194.4 & 19.2 \\
\hline
\end{tabular}


ponds or streams, and no grazing areas. Capybara ecological densities in acurizal ranged from 0.34 to 1.39 capybaras $/ \mathrm{km}^{2}$; this compared to ecological densities in more heavily used habitats of 5.43 to 14.82 capybaras $/ \mathrm{km}^{2}$. Eisenberg, O'Connell \& August (1979) calculated an ecological density of 10 capybaras $/ \mathrm{km}^{2}$ in the llanos of Venezuela.

The most heavily used areas were those that had three habitat components: forest (cordilheiras or capão), a grazing area (campo), and the proximity of water (baias, corixos). Capybaras use the campos for foraging and most other behavioural activities as well. The forest furnishes shelter from the mid-day heat and a resting place at night. The presence of water provides aquatic vegetation, which is an important forage, especially during the rainy season.

Our observations show that the use of these habitats varies seasonally. During the dry season, capybaras spend the night in the forest, between 20.00 and 06.00 or 07.00 . In the early morning they leave the forest and graze in the campos until 11.00 . They return to the forest at 11.00 but at 14.00 they emerge and spend the mid-afternoon (14.00 to 15.00$)$ in the water. From 15.00 to 20.00 , they spend most of their time grazing, occasionally returning to the water. During the rainy season, the capybaras also spend the night (20.00 to 08.00$)$ in the forest, but in the morning usually emerge and go directly to the water instead of grazing in the campos. The rest of the day is spent in the water and in the grazing areas which have not been flooded, with the exception of a brief period between 11.00 and 15.00 , when the animals return to the forest. We observed a substantial increase in the use of aquatic vegetation and forest vegetation in the diet at that time, since little grazing area remains.

Reprotuction occurred year-round, since young of all ages were seen throughtout the year. However, we observed a peak period of births from July to October. The period of greatest recruitment to the adult population occurs between May and October, when the greatest increase in absolute numbers of animals is observed. The greatest increase in the population occurs with the recruitment of young animals which increases group sizes ( $30 \%$ of young).

\section{Social Structure and Use of Space}

We collected 2881 observations of the target capybara group during the year of study. Capybaras have a conspicuous social structure that reflects group sizes. As soon as the sub-adults begin to attain sexual maturity, some are excluded from the social groups by the dominant males. The group size increase from the beginning (rainy season) to the middle of the year (dry season). Capybara groups exhibited annual variations in size, smaller during January-April ( $\bar{x}=7.26 ; 0.55$ SE; $n=860$ and larger during May-December $\bar{x}=11.83 ; 0.94 \mathrm{SE} ; n=964)$. This difference was due to recruitment of young into population. The largest capybara group observed was seen 
during July-August and contained 49 members almost $50 \%$ of them young animals. Groups of 5-10 were relatively common during all months, comprising about $80 \%$ of all the groups. Usually there was one dominant adult male; one or two adult submissive males; four or five adults females and the rest sub-adults or young. During the floods the groups subdivided and are largely confined to the forest patches (cordilheiras and capóes) while in the dry season more animals are observed feeding on the pasture of the campos. At this time of the year there are more young in the group. Due to the social structure, joining and splitting of groups and individuals are common.

The male: female sex ratio for 89 young captured in the field or born in our experimental station was $1: 1$. However, the sex ratio of the adult population in the field is $1: 3$ (males:females). We found the following in ninety-five social groups observed: mean number of males $=1.37, \mathrm{~N}=130$, $0.74 \mathrm{SD}$; mean number of females $=4,00 ; \mathrm{N}=386,2.90 \mathrm{SD}$; mean number of sub-adults $=1.34, \mathrm{~N}=2.39 \mathrm{SD}$, and mean number of young $=3.07$, $\mathrm{N}=292,3.95 \mathrm{SD}$.

About $8 \%$ of the capybaras were solitary or satellite individuals. We found solitary sub-adults injured by other individuals and some were ill and walking with difficulty. One individual captured in that condition showed a very high concentration of Trypanosoma sp. in the flood. It is more common to find solitary sub-adult males or satellite full adult males than lone females. Male groups of two or three members occasionally were seen, but male groups with more than four members were uncommon.

As examination of 948 field observations of aggressive interactions in the Capão do Júlio group showed adult male $\mathrm{x}$ male aggression accounted for $37.85 \%$ adult male $\mathrm{x}$ female $24.23 \%$; adult female $\mathrm{x}$ adult female $12.25 \%$ and adult (both sexes) x sub-adult $29.30 \%$. Aggression between males often involves high levels of combat. Sub-adults of either sex were always subordinate to adults. The dominant male of the group initiated an attack, $15 \%$ of the observed attacks were started by dominant females.

At times aggressive interactions spread through the group and, when this happened, many of the subordinate males and females were excluded for 1-3 h as a result of attacks. Encounters between different groups, in areas where the home ranges overlapped, were characterized by strong fighting between dominant males.

The some range of a group comprises the foraging area, a patch of forest and water. Groups in a preferred habitat occupy a core area of about $1 \mathrm{~km}^{2}$, and may share an additional $2 \mathrm{~km}^{2}$ with other groups.

Several studies on mammalian social structures have revealed that the males' reproductive success is related to the fighting ability of the individual in the group. The male's reproductive sucess is usually limited to the number of breeding females that males have access to in the social group. The result of the intense aggressive interactions between capybara males is a social structure that favors greater number of females and young or sub-adult 
individuals. The number of agonistic interactions per individual increases with group size, from 7.8 for a group of 5 , to 18.4 for a group of 10 , and 18.6 for a group of 15 in captivity (Parra, Escobar \& Gonzales-Jimenez 1978; Ojasti \& Burgos 1985). Aggression increases and reproduction and survival decrease when the group size is larger.

In the Pantanal, the ability of capybaras to adjust to their environment, physical, biological and social, may be indicated by their response to different ecological pressures.

\section{ACKNOWLEDGMENTS}

This research was supported by the IBDF (Departamento de Parques Nacionais e Reservas Equivalentes) in the area of Poconé and by EMBRAPA (Empresa Brasileira de Pesquisa Agropecuária) in the area of Nhecolândia. The research would not have been possible without the help of many field assistants. We would like to thank Tereza Cristina Magro, Júlio Dalponte, Pedro Nonato Conceição, Zilca Maria Campos, Humberto Gonçalves, Estelito, Tito, and many others for their help. Francisco Breyer assisted us in arranging for local research facilities. Thomas E. Lacher, and Anthony B. Rylands reviewed the manuscript.

\section{REFERENCES}

Alho, C.J.R. (1982). Brazilian Rodents: Their Habitats and Habitats. Pp. 143-166 Mammalian Biology in South America (Ed. by M.A. Mares and H.H. Genoways). The Pymatuning Symposia in Ecology, Special Publication Series, Pymatuning Laboratory of Ecology, Unive rsity of Pittsburgh, Pittsburgh, Vol 6: XII +1 - 539. Azcarate, T. (1976). Algunos datos sobre el comportamiento social em una manada de chiguires (Hydrochaerus hydrochaeris). Pp. 13-15, Abstract: II Seminário sobre chiguires (H.h.) y las babas (C.c.). Programas y resumenes, 116 pp. Consejo Nacional de Investigaciones Científicas y Tecnologicas, Caracas.

Ascarate T. (1980). Sociobiologia y manejo del capibara (Hidrochaerus hydrochaeris). Doñana Acta Vertebrados 7 (6): 1-228.

Donaldson, S.L., Wirtz, T.B. \& Hite, A.E. (1975). The social behaviour of capybaras. (Hydrochaerus hydrochaeris) at Evansville Zoo. International Zoo Yearbook 15: 01-206.

Eisenberg, J.F., O'Connell, M.A. \& August, P.V. (1976). Density productivity, and distribution of mammals in two Venezuelan habitats. Pp. 187-207 Vertebrate Ecology in the Northern Neotropics (Ed. by J.F. Eisenberg). The National Zoological Park, Smithsonian Institution Washington, D.C., U.S.A.

Escobar, A. \& Gonzalez-Jimenez, E. (1975). Estudio de la competencia alimenticia de los herbivoros mayores def llano inundable con referencia especial al chiguirre. Agronomia Tropical, 26:215-227.

Gil, A., Perea J. \& Ruiz, S. (1976). Habitos territoriales y comportamiento social del 
Gil, A., Perea J. \& Ruiz, S. (1976). Habitos territoriales y comportamiento social del "chiguirre" (H.h.h.) Pp. 11-12 II Seminario sobre chiguirres (H.h.) y las babas (C.c.). Consejo Nacional de Investigaciones Científicas y Tecnologicas, Caracas, $116 \mathrm{pp}$.

Gonzales-Jimenez, E. (1977). The capy bara - an indigenous source of meat in Tropical America. World Animal Review (FAO), $21: 24-30$.

MacDonald, D.W. (1981). Dwindling resources and the social behaviour of capybaras (Hidrochaerus hydrochaeris) (Mammalia). Journal of Zoology (London), 194 : 371-391.

MacDonald, D.W., Krantz, K. \& Aplin, R.T. (1984). Behavioural anatomical and chemical aspects of scent marking amongst capybaras (Hydrochaerus hydrochaeris) (Rodentia: caviomorpha). Journal of Zoology (London) 202:341-360.

Ojasti, J. (1968). Notes on the mating behaviour of the capybara. Journal of Mamma$\log y, 49: 534-535$.

Ojasti, J. (1973). Estudio biologico del chiguirre o capybara. Fondo Nacional de Investigaciones Agropecuarias, Editorial Sucre, Caracas, 275 pp.

Ojasti, J. (1978). The relation between population and production of capybara (Hydrochaerus hydrochaeris). Unpubl. Ph.D. dissert., University of Georgia, Athens, U.S.A., $\mathrm{xi}+204$ pp.

Ojasti, J. \& Medina-Padilla, G. (1972). The management of capybara in Venezuela, Transactions North American Wildlife and Natural Resources Conference, 37:268-277.

Ojasti, J. \& Burgos, L.J. (1985). Density regulation in population of capybaras. Acta Zoologica Fennica 173:81-83.

Parra, R., Escobar, A. \& Gonzales-Jimenez, E. (1978). El chiguire, su potencial biológico y su cría en confinamiento. Informe Anual de Instituto de Procucion Animal (Maracay): 83-93.

Pott, A. (1982). Pastagens das sub-regiões dos Paiaguás e da Nhecolândia do Pantanal matogrossense. EMBRAPA. Circular Técnica no 10,49 pp.

Rewell, R.E. (1950). Hypertrophy of sebaceous glands on the snout as a secondary male sexual character in the capybara (Hidrochaerus hidrochaeris). Proceedings of the Zoological Society of London, 119:817-819.

Schaller, G.B. \& Crawshaw, Jr. P.G. (1981). Social organization in a capybara population. Saugetierkundliche Mitteilungen 29 (1): 3-16.

Zara, J.L. (1973). Breeding and husbandry of the capybara (Hidrochaerus hydrochaeris) at Evansville Zoo. International Zoo Yearbook, 13: 137-139. 